\title{
Lymphatic mapping and sentinel node biopsy in ovarian tumors: a study using intra-operative Tc-99m-Phytate and lymphoscintigraphy imaging
}

Malihe Hassanzadeh ${ }^{1}$, Elham Hosseini Farahabadi ${ }^{1}$, Zohreh Yousefi', Sima Kadkhodayan', Leili Zarifmahmoudi ${ }^{2}$ and Ramin Sadeghi ${ }^{2^{*}}$ (D)

\begin{abstract}
Background: Experience on sentinel node mapping in ovarian tumors is very limited. We evaluated the sentinel node concept in ovarian tumors using intra-operativeTc-99m-Phytate injection and lymphoscintigraphy imaging.

Methods: Thirty-five patients with a pelvic mass due to an ovarian pathology were included in the study. The radiotracer was injected just after laparotomy and before removal of the tumor either beneath the normal cortex (10 patients) or in the utero-ovarian and suspensory ligaments of the ovary just beneath the peritoneum two injections of the radiotracer (25 patients). For malignant masses, the sentinel nodes were identified using a hand held gamma probe. Then standard pelvic and para-aortic lymphadenectomy was performed. In case of benign pathologies or borderline ovarian tumors on frozen section, lymphadenectomy was not performed. The morning after surgery, all patients were sent for lymphoscintigraphy imaging of the abdomen and pelvis.

Results: Sentinel node was identified only in 4 patients of the cortical injection group. At least one sentinel node could be identified in 21 patients of the sub-peritoneal group. Sentinel nodes were identified only in the para-aortic area in 21, pelvic/para-aortic areas in 2, and pelvic only area in 2 patients. Three patients had lymph node involvement and all had involved sentinel nodes (no false negative case).
\end{abstract}

Conclusion: Sentinel node mapping using intra-operative injection of the radiotracer (in the utero-ovarian and suspensory ligaments of the ovary just beneath the peritoneum) is feasible in ovarian tumors. Technical aspects of this method should be explored in larger multicenter studies in the future.

Keywords: Ovary, Ovarian tumor, Sentinel, Lymphoscintigraphy, Lymphatic mapping, Blue dye

\section{Background}

Epithelial ovarian cancer is the most common ovarian malignancy and is the leading cause of death from gynecological cancers in the United States [1, 2]. About a third of epithelial ovarian cancers presents in an early stage [3]. Para-aortic and pelvic lymph node dissection is the recommended procedure for lymph node staging of epithelial ovarian cancers [4]. However routine lymph node dissection did not show any survival benefit even

\footnotetext{
*Correspondence: sadeghir@mums.ac.ir; raminsadeghi1355@yahoo.com ${ }^{2}$ Nuclear Medicine Research Center, Mashhad University of Medical Sciences, Mashhad, Iran

Full list of author information is available at the end of the article
}

in advanced ovarian cancers [5]. Incidence of lymph node involvement in the early ovarian cancers (stage I) is also low (about 10-20\%) [6] and majority of patients with early ovarian cancer would not benefit from routine lymphadenectomy while being subject to its unwanted consequences such as prolonged hospitalization, more blood loss, and longer surgical time [7, 8].

In the last two decades, sentinel node mapping has been introduced to the surgical management of many solid tumors. Although lymphatic mapping has been applied successfully for gynecological and urological cancers [9-14], it has not been adequately evaluated for ovarian cancers in the medical literature: To the extent 
of our knowledge only four studies thus far is available in this regard [15-18].

In the current study, we evaluated the sentinel node concept in ovarian tumors using intra-operativeTc-99mPhytate injection and lymphoscintigraphy imaging.

\section{Methods}

During a period from Jan 2010 to Oct 2014, 35 patients with a pelvic mass diagnosed to be due to an ovarian pathology were eligible to be included in the study. All patients provided written informed consent before enrollment in the study, and the study was approved by the Local Ethical Committee of Mashhad University of Medical Sciences under the approval number of 931331. Pregnant or lactating patients, patients with the history of previous surgery on one or both ovaries; previous lymph node surgery in the pelvic or para-aortic areas; a history of any malignant tumor in the abdominal or pelvic cavities were excluded from the study.

\section{Sentinel node mapping}

We used Tc-99m-Phytate for lymphatic mapping in all patients. The radiotracer was injected just after laparotomy and before removal of the tumoral ovary. The first 10 patients received two injections of the radiotracer $(1 \mathrm{mCi} / 0.2 \mathrm{~mL} /$ injection) beneath the normal cortex of the ovary. The remainder of the patients received two injections of the radiotracer $(1 \mathrm{mCi} / 0.2 \mathrm{~mL}$ each $)$ in the utero-ovarian and suspensory ligaments of the ovary just beneath the peritoneum close to the diseased ovary (Fig. 1). In four patients of the second group, patent blue $\mathrm{V}$ dye was also injected in the same location as the radiotracer ( $0.2 \mathrm{cc}$ /injection).

The surgeon waited for $10 \mathrm{~min}$ interval before removal of the adnexal mass in order to give the radiotracer enough time to move in the lymphatics. The adnexal mass was then sent to the pathologist for frozen section evaluation. For malignant masses, the sentinel nodes were identified using a hand held gamma probe (EUROPROBE, Lyon, France) by searching the para-aortic and pelvic areas. Any lymph node with 3 times more count than the background was considered a sentinel node and was harvested separately for histopathological evaluation using H\&E staining. Then standard pelvic and para-aortic lymphadenectomy was performed.

In case of benign pathologies or borderline ovarian tumors on frozen section, lymphadenectomy was not performed. However the gamma probe was used to locate any hot area in the pelvic and par-aortic areas and the locations of any hot spots were recorded.

The morning after surgery, all patients were sent to the nuclear medicine ward for lymphoscintigraphy imaging of the abdomen and pelvis. Anterior and lateral views (5 min/image) of the abdomen and pelvis were taken by a dual head variable angle gamma camera (E.CAM, SIEMENS, Germany) equipped with low energy all-purpose collimator and Tc-99m photopeak [19]. The images were interpreted by two nuclear medicine specialists familiar with sentinel node mapping and the results were correlated with the intraoperative findings.

\section{Results}

Overall 35 patients entered the study. Table 1 shows the characteristics of the patients. Ten patients had cortical injection of the tracer ( 3 with malignant and 7 with benign ovarian pathology). Sentinel node was identified only in 4 patients of this group which amounts to $40 \%$ detection rate ( 2 with benign and 2 with malignant pathology). Twenty-five patients received sub-peritoneal ligament injection of the mapping material (10 with malignant, one with borderline pathology and 13 with benign pathology). At least one sentinel node could be identified in 21 patient of
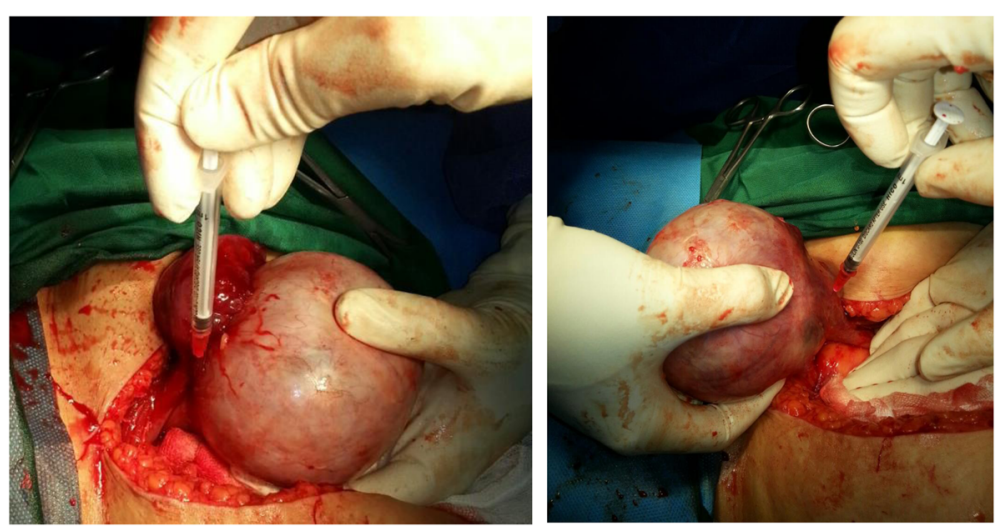

Fig. 1 Radiotracer injection in the utero-ovarian and suspensory ligaments of the ovary just beneath the peritoneum 
Table 1 Characteristics of the included patients

\begin{tabular}{|c|c|c|c|c|c|}
\hline $\mathrm{N}$ & $\begin{array}{l}\text { Age/tumor side/tumor } \\
\text { size }(\mathrm{cm})\end{array}$ & $\begin{array}{l}\text { Injection } \\
\text { location }\end{array}$ & $\begin{array}{l}\text { Final pathological } \\
\text { results }\end{array}$ & $\begin{array}{l}\text { Number and location of sentinel } \\
\text { nodes on lymphoscintigraphy findings }\end{array}$ & Comments \\
\hline 1 & $28 /$ left/12 $\times 8$ & $\mathrm{~L}$ & Benign follicular cyst & Two/para-aortic & - \\
\hline 2 & 16/right/7×7 & C & Struma ovarii & Three/para-aortic & - \\
\hline 3 & $54 /$ left/20 $\times 25$ & $L$ & Serous cysadenofibroma & One/para-aortic & - \\
\hline 4 & $35 /$ left/10 $\times 9$ & $L$ & Mature teratoma & Two/para-aortic & - \\
\hline 5 & $45 /$ left/20 $\times 15$ & C & Granulosa cell tumor & $\begin{array}{l}\text { No remaining activity in the } \\
\text { pelvis and abdomen }\end{array}$ & $\begin{array}{l}\text { TAH + BSO + APAL: Two hot sentinel nodes } \\
\text { were identified during surgery in the para-aortic } \\
\text { area. Sentinel nodes were not involved. No } \\
\text { other lymph node involvement. }\end{array}$ \\
\hline 6 & $42 /$ right/ $15 \times 10$ & L & $\begin{array}{l}\text { Mature teratoma with } \\
\text { ovarian torsion }\end{array}$ & None & - \\
\hline 7 & $51 /$ left/10 $\times 10$ & L & $\begin{array}{l}\text { Benign papillary serous } \\
\text { cyst with ovarian torsion }\end{array}$ & None & - \\
\hline 8 & $17 /$ left/ $7 \times 7$ & L & Benign serous cyst & Two/para-aortic & - \\
\hline 9 & $26 / l e f t / 10 \times 5$ & $\mathrm{~L}$ & Benign luteal cyst & One/para-aortic & - \\
\hline
\end{tabular}

$1032 /$ right $/ 8 \times 10 \quad L \quad$ Mucinous No remaining activity in the adenocarcinoma pelvis and abdomen

\begin{tabular}{|c|c|c|c|}
\hline 11 & 52/right/12 × 15 & L & $\begin{array}{l}\text { Borderline serous } \\
\text { cystadenoma }\end{array}$ \\
\hline 12 & 59/right/6×8 & C & Mature teratoma \\
\hline 13 & $56 /$ right/12 $\times 9$ & C & $\begin{array}{l}\text { Papillary serous } \\
\text { adenocarcinoma }\end{array}$ \\
\hline 14 & $36 /$ left/7 $\times 6$ & L & $\begin{array}{l}\text { Mature teratoma with } \\
\text { ovarian torsion }\end{array}$ \\
\hline 15 & $47 /$ right/5 $\times 7$ & L & $\begin{array}{l}\text { Papillary serous } \\
\text { adenocarcinoma }\end{array}$ \\
\hline
\end{tabular}

\begin{tabular}{|c|c|c|c|c|}
\hline 16 & 42/right/12 × 13 & - & Thechoma & One/Para-aortic \\
\hline 17 & $31 /$ right/ $6 \times 6$ & L & Benign serous cyst & One/Para-aortic \\
\hline 18 & $42 /$ right/ $6 \times 8$ & C & $\begin{array}{l}\text { Benign mucinous } \\
\text { cystadenoma with } \\
\text { ovarian torsion }\end{array}$ & None \\
\hline 19 & 60/Bilateral/10 × 8;6 ×8 & $\mathrm{L}$ & $\begin{array}{l}\text { Papillary serous } \\
\text { adenocarcinoma }\end{array}$ & $\begin{array}{l}\text { No remaining activity in the } \\
\text { pelvis and abdomen }\end{array}$ \\
\hline
\end{tabular}

$\begin{array}{llll}2042 / \text { right } / 10 \times 10 & C & \begin{array}{l}\text { Benign mucinous } \\ \text { cystadenoma }\end{array} & \text { None } \\ 2168 / \text { left } / 6 \times 8 & L & \begin{array}{l}\text { Benign mucinous } \\ \text { cystadenoma }\end{array} & \text { One/Para-aortic } \\ 2240 / \text { left } / 6 \times 8 & L & \begin{array}{l}\text { Benign mucinous } \\ \text { cystadenoma }\end{array} & \text { One/Para-aortic } \\ 2326 / \text { left/ } 6 \times 5 & C & \begin{array}{l}\text { Granulosa cell tumor } \\ \text { No remaining activity in the } \\ \text { pelvis and abdomen }\end{array}\end{array}$

No remaining activity in the pelvis and abdomen

\section{Two/para-aortic}

No remaining activity in the pelvis and abdomen

None

No remaining activity in the pelvis and abdomen pelvis and abdomen pelvis and abdomen
$\mathrm{TAH}+\mathrm{BSO}+\mathrm{APAL}:$ Three hot sentinel nodes were identified during surgery in the para-aortic area. None were involved. No lymph node involvement.

$\mathrm{TAH}+\mathrm{BSO}+\mathrm{APAL}:$ One hot sentinel node was identified during surgery in the para-aortic area. None were involved. No lymph node involvement.

TAH + BSO + APAL: No hot sentinel node was identified during surgery in the para-aortic area. No lymph node involvement.

TAH + BSO + APAL: Two hot sentinel nodes was identified during surgery in the para-aortic (one) and pelvic areas (one in the internal iliac area). None were involved. No lymph node involvement.

$-$

$-$

$-$

TAH + BSO + APAL: Three hot sentinel nodes was identified during surgery in the para-aortic (two) and pelvic areas (one in the obturator). Both were involved. No other lymph node involvement.

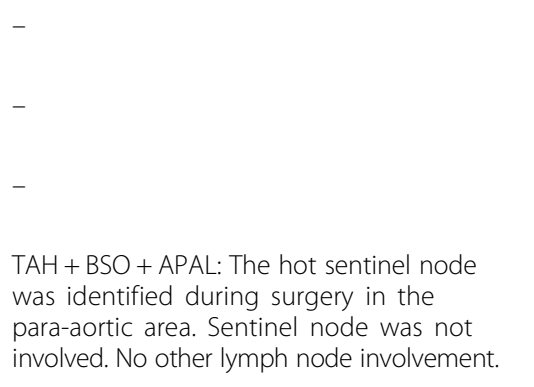


Table 1 Characteristics of the included patients (Continued)

\begin{tabular}{|c|c|c|c|c|c|}
\hline 24 & $45 / \mathrm{left} / 7 \times 6$ & $\mathrm{~L}$ & $\begin{array}{l}\text { Papillary serous } \\
\text { adenocarcinoma }\end{array}$ & $\begin{array}{l}\text { No remaining activity in the } \\
\text { pelvis and abdomen }\end{array}$ & $\begin{array}{l}\text { TAH + BSO + APAL: Two hot sentinel nodes } \\
\text { were identified during surgery in the } \\
\text { para-aortic (one) and external iliac (one) } \\
\text { areas. Sentinel nodes were not involved. } \\
\text { No other lymph node involvement. }\end{array}$ \\
\hline 25 & $22 /$ right/10 × 11 & $L$ & Benign serous cyst & One/Para-aortic & - \\
\hline 26 & $57 /$ right/ $8 \times 9$ & $L$ & $\begin{array}{l}\text { Papillary serous } \\
\text { adenocarcinoma }\end{array}$ & $\begin{array}{l}\text { No remaining activity in the } \\
\text { pelvis and abdomen }\end{array}$ & $\begin{array}{l}\text { TAH + BSO + APAL: The hot sentinel node } \\
\text { was identified during surgery in the } \\
\text { para-aortic area. Sentinel node was not } \\
\text { involved. No other lymph node involvement. }\end{array}$ \\
\hline 27 & $\begin{array}{l}\text { 43/Bilateral/11 } \times \\
12 ; 10 \times 6\end{array}$ & $L$ & $\begin{array}{l}\text { Papillary serous } \\
\text { adenocarcinoma }\end{array}$ & $\begin{array}{l}\text { No remaining activity in the } \\
\text { pelvis and abdomen }\end{array}$ & $\begin{array}{l}\text { TAH + BSO + APAL: The hot sentinel nodes } \\
\text { were identified during surgery in the } \\
\text { para-aortic (two sentinel nodes) and pelvic } \\
\text { areas (right common iliac). None were } \\
\text { involved. No other lymph node involvement. }\end{array}$ \\
\hline 28 & $36 /$ right/11 × 10 & $\mathrm{~L}$ & Benign serous cyst & One/Para-aortic & - \\
\hline 29 & $\begin{array}{l}35 / \text { Bilateral/10 } \times \\
10 ; 10 \times 7\end{array}$ & L & $\begin{array}{l}\text { Papillary serous } \\
\text { adenocarcinoma }\end{array}$ & $\begin{array}{l}\text { No remaining activity in the } \\
\text { pelvis and abdomen }\end{array}$ & $\begin{array}{l}\text { TAH + BSO + APAL: Two hot (and blue) sentinel } \\
\text { nodes were identified during surgery in the } \\
\text { para-aortic area. One sentinel node was } \\
\text { pathologically involved. No other lymph } \\
\text { node involvement. }\end{array}$ \\
\hline 30 & 50/right/7×8 & $\mathrm{L}$ & $\begin{array}{l}\text { Papillary serous } \\
\text { adenocarcinoma }\end{array}$ & $\begin{array}{l}\text { No remaining activity in the } \\
\text { pelvis and abdomen }\end{array}$ & $\begin{array}{l}\text { TAH + BSO + APAL: The hot (and blue) sentinel } \\
\text { node was identified during surgery in the } \\
\text { pelvic area (external iliac). Sentinel node was } \\
\text { not involved. No other lymph node } \\
\text { involvement. }\end{array}$ \\
\hline 31 & 43/Right/10 × 10 & L & $\begin{array}{l}\text { Papillary serous } \\
\text { adenocarcinoma }\end{array}$ & $\begin{array}{l}\text { No remaining activity in the } \\
\text { pelvis and abdomen }\end{array}$ & $\begin{array}{l}\text { TAH + BSO + APAL: The hot (and blue) sentinel } \\
\text { node was identified during surgery in the } \\
\text { pelvic area (external iliac). Sentinel node was not } \\
\text { involved. No other lymph node involvement. }\end{array}$ \\
\hline 32 & 36/Right/10 × 12 & L & $\begin{array}{l}\text { Benign mucinous } \\
\text { cystadenoma }\end{array}$ & One/Para-aortic & - \\
\hline 33 & 35/Bilateral/10 × 8;8 ×8 & L & $\begin{array}{l}\text { Papillary serous } \\
\text { adenocarcinoma }\end{array}$ & $\begin{array}{l}\text { No remaining activity in the } \\
\text { pelvis and abdomen }\end{array}$ & $\begin{array}{l}\text { TAH + BSO + APAL: Two hot (and blue) sentinel } \\
\text { nodes were identified during surgery in the } \\
\text { para-aortic area. One of the sentinel nodes was } \\
\text { involved. One non-sentinel node in the } \\
\text { para-aortic was also involved. }\end{array}$ \\
\hline 34 & 45/Left/7×7 & C & Benign serous cyst & None & - \\
\hline 35 & $37 /$ Left/ $8 \times 8$ & C & Benign serous cyst & None & - \\
\hline
\end{tabular}

this group which amounts to $84 \%$ detection rate (11 with malignant and 10 with benign pathology).

Four patients had ovarian torsion in addition to their underlying pathology in the ovary. No sentinel node could be identified in these patients.

Sentinel nodes were identified only in the para-aortic area in all 12 patients with benign pathology and successful lymphatic mapping. Sentinel nodes were identified in para-aortic area in 9 and pelvic/para-aortic areas in 2 patients and pelvic only area in 2 patients with malignant pathology.

In four patients who received blue dye injection in addition to radiotracer, all sentinel nodes were hot/blue. Figure 2 shows a blue para-aortic sentinel node in one of these patients.

Three patients with malignant pathology had lymph node involvement and all had involved sentinel nodes on pathology (100\% sensitivity and no false negative case). No adverse reaction to the radiotracer or blue dye was observed in our patients.

Figure 3 shows lymphoscintigraphy images of patient number 8 .

\section{Discussion}

Thus far, only limited studies on lymphatic mapping in ovarian cancer have been published. Table 2 summarizes the data of these studies in addition to the current one. Two studies were done on normal ovaries of patients who underwent laparotomy for other reasons $[15,16]$. Both studies reported a high sentinel node detection rate. Vanneaville et al. study used a laparoscopic mesovarian radiotracer injections in the normal ovaries of 14 patients who were treated for benign ovarian cysts or were candidate of tubal ligation. Sentinel nodes were 


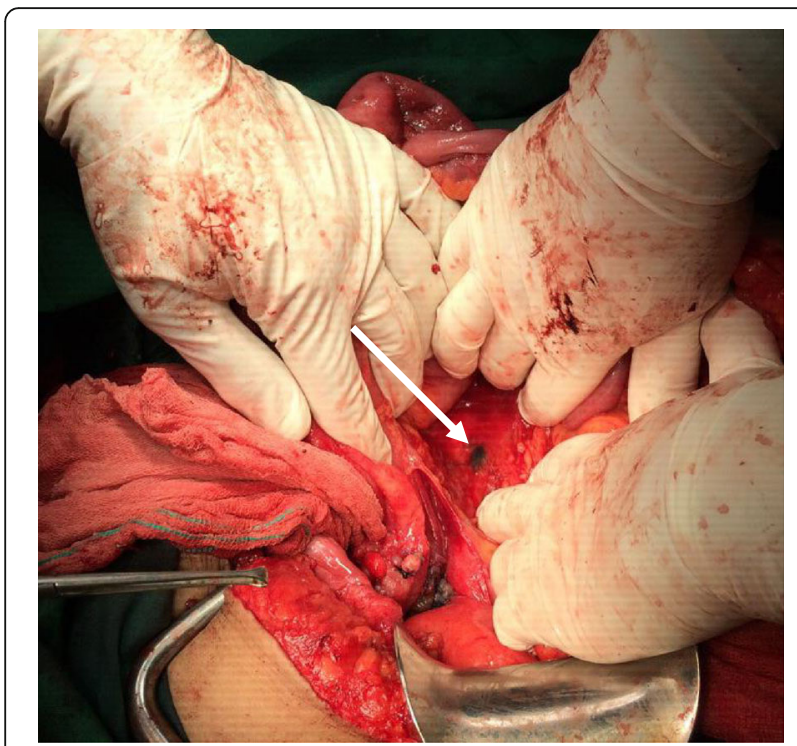

Fig. 2 A blue para-aortic sentinel node could be identified in this patient intra-operatively (arrow)

detected 4-6 h post injection by planar lymphoscintigraphy. In 12 patients sentinel nodes could be identified (4 para-aortic and 8 pelvic/para-aortic). Isolated para-aortic drainage was more prominent in the post-menopausal (75\%) as compared to the pre-menopausal patients $(12.5 \%)$ [18, 20].

An important study published by Kleppe et al. reported the first experience on sentinel node mapping in ovarian tumors. They used radiotracer/blue dye injection into the proper ovarian ligament and the suspensory ligament and reported $100 \%$ detection rate and sensitivity $[17,21]$.

Our study showed that intra-operative injection of radiotracer is a feasible method for lymphatic mapping and sentinel node biopsy in ovarian tumors. Intraoperative injection of sentinel node mapping materials has been reported to be very successful for lymphatic mapping in other solid tumors too; such as lung, gynecological, and urological tumors [11, 12, 22]. This is possible due to very rapid movement of the radiotracer in the lymphatic vessels especially those with small particle size [23-25]. In the current study we used Tc-99m Phytate which has a small particle size with rapid lymphatic movement as shown in other studies before [26-30]. Negishi et al., Nyberg et al., and Kleppe st al. used $10 \mathrm{~min}, 10-21 \mathrm{~min}$, and $15 \mathrm{~min}$ after injection, respectively. All these three studies had excellent sentinel node detection rate. We waited for 10 min after injection with comparable detection rate too. Overall, it seem that 10 to $15 \mathrm{~min}$ is an optimal time to wait after mapping material injection in ovarian cancers.

Two injection methods were used in our study: subcortical vs. sub-peritoneal. Subcortical injection of the radiotracer was not successful enough (40\% detection rate). Finding normal cortex in the tumoral ovaries can be very hard and carries the risk of tumor puncture and it seems that sub-cortical injection of the mapping material is not a viable method for lymphatic mapping in ovarian cancers. On the other hand injection of the tracer beneath the peritoneum of the suspensory and utero-ovarian ligaments was highly successful for lymphatic mapping (84 \% detection rate). All sentinel node detection failure in this group occurred in patients with ovarian torsion (3 patients) which can disrupt the lymphatic flow of the ovaries. Our results are in accordance with Kleppe et al. report as they also had a very high detection rate using the same injection method as we used in our study $[17,21]$.

We used a combination method (blue dye/radiotracer) in four patients and all four patients had blue paraaortic sentinel nodes. Adding blue dye to radiotracer (dual mapping method) has been shown to be an effective method for decreasing sentinel node detection failure as well as false negative cases in many tumors [31-33]. However, Kleppe et al. showed that blue dye was successful only in 2 patients out of 6 with retro-peritoneal exploration and ascribed it to the long time between blue dye injection and exploration [17]. Considering the possibility of adverse reactions to blue dyes [34, 35], the added value of blue dye injection should be evaluated in more detail in the future studies.

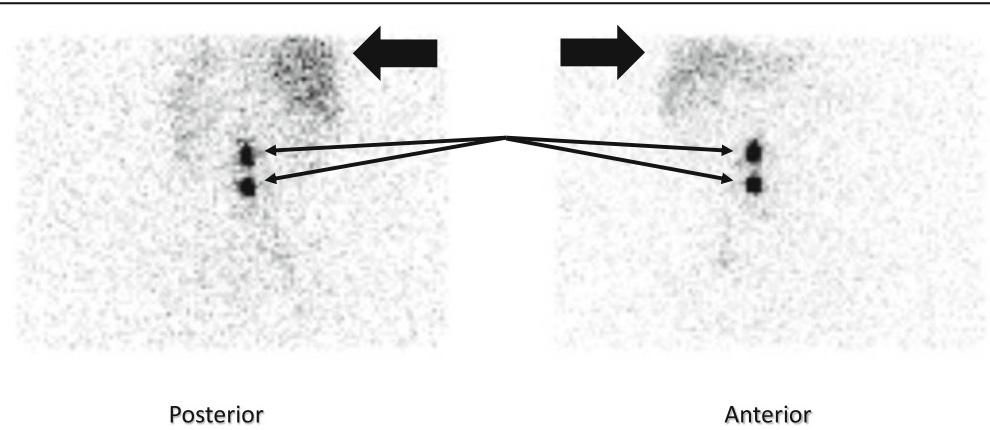

Fig. 3 Planar anterior/posterior lymphoscintigraphy images of a patient. Two para-aortic sentinel nodes are marked by arrows. Activity in the liver is also apparent (black arrows) 
Table 2 Summary of the studies on lymphatic mapping of the ovaries

\begin{tabular}{|c|c|c|c|c|}
\hline First author/year & Included patients & Mapping material & Injection site & Main results \\
\hline Kleppe/2014 & $\begin{array}{l}21 \text { patients diagnosed with } \\
\text { a pelvic mass suggestive of } \\
\text { a malignant ovarian tumor }\end{array}$ & $\begin{array}{l}\text { Blue dye/ } \\
\text { Radiotracer }\end{array}$ & $\begin{array}{l}\text { On the dorsal and ventral side of } \\
\text { the proper ovarian ligament and } \\
\text { the suspensory ligament, close } \\
\text { to the ovary and just underneath } \\
\text { the peritoneum }\end{array}$ & $\begin{array}{l}\text { Al least one sentinel node } \\
\text { could be identified in all } \\
\text { patients (100\% detection } \\
\text { rate). Para-aortic region only } \\
\text { in } 67 \% \text {, pelvic region only } \\
\text { in } 9 \% \text {, and in both in } 24 \% \text {. } \\
\text { No false negative case }\end{array}$ \\
\hline Negishi/2004 & $\begin{array}{l}11 \text { women with endometrial } \\
\text { or fallopian tube tumors }\end{array}$ & Activated Charcoal & Into the unilateral cortex of the ovary & $\begin{array}{l}\text { Sentinel node could be } \\
\text { identified in all patients: } \\
\text { para-aortic in all patients, } \\
\text { common iliac node in } \\
\text { three, and external iliac in one }\end{array}$ \\
\hline Nyberg/2011 & $\begin{array}{l}16 \text { patients with high-risk uterine } \\
\text { cancer and normal postmenopausal } \\
\text { ovaries }\end{array}$ & $\begin{array}{l}\text { Blue dye/ } \\
\text { Radiotracer }\end{array}$ & $\begin{array}{l}\text { Slow injection near the hilum of } \\
\text { one ovary }\end{array}$ & $\begin{array}{l}\text { Sentinel node could be } \\
\text { identified in } 15 \text { patients } \\
\text { (93.75\% detection rate). } \\
\text { All were located in the } \\
\text { para-aortic area. }\end{array}$ \\
\hline \multirow[t]{2}{*}{ Vanneaville/1991 } & $\begin{array}{l}14 \text { patient who were investigated } \\
\text { by laparoscopy, either for ablation } \\
\text { of a benign ovarian cyst or for } \\
\text { tubal ligation }\end{array}$ & Radiotracer & $\begin{array}{l}\text { Injection into the mesovarium } \\
\text { of the normal ovaries during } \\
\text { laparoscopy. }\end{array}$ & $\begin{array}{l}\text { Lymphatic drainage could } \\
\text { be discerned in } 12 \text { patients. } \\
\text { Isolated para-aortic sentinel } \\
\text { nodes in } 4 \text {, combined pelvic/ } \\
\text { para-aortic sentinel nodes in } 8 .\end{array}$ \\
\hline & & & $\begin{array}{l}\text { Lymphatic drainage was investigated } \\
\text { by lymphoscintigraphy } 4-6 \mathrm{~h} \\
\text { post-injection. }\end{array}$ & $\begin{array}{l}\text { Isolated para-aortic drainage } \\
\text { was more prominent in the } \\
\text { post-menopausal }(75 \%) \text { as } \\
\text { compared to the pre-menopausal } \\
\text { patients }(12.5 \%) \text {. }\end{array}$ \\
\hline The current study & 35 patients with ovarian tumors & Radiotracer & $\begin{array}{l}\text { Sub-cortical in } 11 \text { and sub-peritoneal } \\
\text { (ovarian and suspensory ligaments) } \\
\text { in } 24\end{array}$ & $\begin{array}{l}\text { Detection rate of } 40 \% \text { in the } \\
\text { sub-cortical and } 84 \% \text { in the } \\
\text { sub-peritoneal group. Sentinel } \\
\text { nodes were identified in } 21 \\
\text { patient in the para-aortic area } \\
\text { only and in } 4 \text { in the pelvic/ } \\
\text { para-aortic area. No false negative } \\
\text { case was identified }\end{array}$ \\
\hline
\end{tabular}

Imaging of the sentinel nodes using lymphoscintigraphy is an important method which is integrated in lymphatic mapping of the solid tumors [19, 30, 36-39]. We also used lymphoscintigraphy for all patients postoperatively. For patients with benign pathology; who did not underwent lymph node dissection, this is the only method to show the exact location of the sentinel nodes. For patients with malignant tumors, lymphoscintigraphy could confirm the complete resection of the sentinel nodes. Kleppe et al. didn't use lymphoscintigraphy and for benign ovarian tumors relative intra-operative count of the para-aortic or pelvic areas was used as the surrogate of the sentinel node detection. This is a limitation of Kleppe et al. study which we avoided by adding postoperative lymphoscintigraphy to our study $[17,21]$. In the future studies, application of intra-operative gamma cameras as well as SPECT/CT methods should be evaluated for sentinel node mapping in ovarian cancers.

The location of sentinel nodes in our study was also in accordance with the known primary lymphatic drainage pattern of the ovaries [18]: isolated para-aortic drainage in $84 \%$, isolated pelvic drainage in $8 \%$ and combined pelvic/para-aortic in $8 \%$ of the patients with successful lymphatic mapping. The variable lymphatic drainage pattern of the ovaries can be problematic in sentinel node mapping. Intra-operative gamma camera and pre-operative SPECT/CT can be of particular use in localization of the ovarian sentinel nodes and future studies should investigate these flourishing technologies.

False negative rate is another important index of the sentinel node mapping studies and should be considered alongside the detection rate in all sentinel node mapping feasibility study [40]. In the Kleppe et al. study, only one patient had involved nodes which were detected by sentinel node mapping [17]. In our study, three patients had involved lymph nodes and all were correctly identified by sentinel node biopsy (false negative rate of $0 \%$ which means $100 \%$ sensitivity). This is promising, however more studies with larger sample size is needed to confirm the results of our study. Specificity is not reported in our study as specificity of sentinel node mapping is always $100 \%$ and no false positive case is possible. As sentinel node is a part 
of the lymphatic basin, pathologically involved sentinel node invariably means involved lymphatic basin and false positive case is impossible.

If the results of our study would be corroborated in the larger multicenter trials, para-aortic and pelvic lymph node dissection can be omitted in patients with non-involved sentinel nodes.

The radiation safety of sentinel node mapping has been addressed before in several studies [41]. Radiation dose to the patients is very low as systemic absorption of the tracer is minimal and the injection site is removed from the body during surgery [42]. Radiation to the surgical and nuclear medicine staff as well as the pathologists is also well below the ICRP threshold limit [43].

\section{Conclusion}

Sentinel node mapping using intra-operative injection of the radiotracer is feasible in ovarian tumors. It seems to be an accurate method for detection of the patients with involved lymph nodes. Tracer injection in the uteroovarian and suspensory ligaments of the ovary just beneath the peritoneum seems to be an efficient method for lymphatic mapping, however technical aspects of this method should be explored in larger multicenter studies in the future.

\section{Acknowledgements}

Not applicable

\section{Funding}

The current study was funded by a grant from the vice chancellery of research of Mashhad University of Medical Sciences.

\section{Availability of data and materials}

All data supporting the conclusion of our manuscript would be available upon request from the corresponding author. Public storage of the clinical data of the patients was not approved by the local ethical committee of our institute.

\section{Authors' contributions}

Study concepts: RS, MH, EH, SK. Study design: MH, EH, ZY, RS. Data acquisition: EH, LZ, SK. Quality control of data and algorithms: EH, RS, LZ. Data analysis and interpretation: RS, LZ, ZY. Statistical analysis: RS. Manuscript preparation: RS. Manuscript editing: All authors. Manuscript review: All authors. All authors read and approved the final manuscript.

\section{Competing interests}

The authors declare that they have no competing interests.

\section{Consent for publication}

Not applicable.

\section{Ethics approval and consent to participate}

All patients provided written informed consent before enrollment in the study, and the study was approved by the Local Ethical Committee of Mashhad University of Medical Sciences under the approval number of 931331.

\section{Author details}

'Women's Health Research Center, Mashhad University of Medical Sciences, Mashhad, Iran. ${ }^{2}$ Nuclear Medicine Research Center, Mashhad University of Medical Sciences, Mashhad, Iran.
Received: 18 April 2016 Accepted: 5 September 2016

Published online: 07 September 2016

\section{References}

1. Jelovac D, Armstrong DK. Recent progress in the diagnosis and treatment of ovarian cancer. CA Cancer J Clin. 2011;61(3):183-203.

2. Siegel R, Ma J, Zou Z, Jemal A. Cancer statistics, 2014. CA Cancer J Clin. 2014;64(1):9-29.

3. Holschneider $\mathrm{CH}$, Berek JS. Ovarian cancer: epidemiology, biology, and prognostic factors. Semin Surg Oncol. 2000;19(1):3-10.

4. Angioli R, Plotti F, Palaia I, Calcagno M, Montera R, Cafa EV, Sereni MI, Panic PB. Update on lymphadenectomy in early and advanced ovarian cancer. Curr Opin Obstet Gynecol. 2008:20(1):34-9.

5. Panici PB, Maggioni A, Hacker N, Landoni F, Ackermann S, Campagnutta E, Tamussino K, Winter R, Pellegrino A, Greggi S, et al. Systematic aortic and pelvic lymphadenectomy versus resection of bulky nodes only in optimally debulked advanced ovarian cancer: a randomized clinical trial. J Natl Cancer Inst. 2005;97(8):560-6.

6. Takeshima N, Hirai Y, Umayahara K, Fujiwara K, Takizawa K, Hasumi K. Lymph node metastasis in ovarian cancer: difference between serous and nonserous primary tumors. Gynecol Oncol. 2005;99(2):427-31.

7. Maggioni A, Benedetti Panici P, Dell'Anna T, Landoni F, Lissoni A, Pellegrino A, Rossi RS, Chiari S, Campagnutta E, Greggi S, et al. Randomised study of systematic lymphadenectomy in patients with epithelial ovarian cancer macroscopically confined to the pelvis. Br J Cancer. 2006;95(6):699-704.

8. Ulanday KT, Ward KK, Macera CA, Ji M, Plaxe SC. Regional variation in surgical assessment of lymph nodes for staging among women with earlystage epithelial ovarian cancer. Gynecol Oncol. 2014;132(2):411-5.

9. Hassanzade M, Attaran M, Treglia G, Yousefi Z, Sadeghi R. Lymphatic mapping and sentinel node biopsy in squamous cell carcinoma of the vulva: systematic review and meta-analysis of the literature. Gynecol Oncol. 2013;130(1):237-45.

10. Ansari M, Rad MA, Hassanzadeh M, Gholami H, Yousefi Z, Dabbagh VR, Sadeghi R. Sentinel node biopsy in endometrial cancer: systematic review and meta-analysis of the literature. Eur J Gynaecol Oncol. 2013;34(5):387-401.

11. Sadeghi R, Gholami H, Zakavi SR, Kakhki VR, Tabasi KT, Horenblas S. Accuracy of sentinel lymph node biopsy for inguinal lymph node staging of penile squamous cell carcinoma: systematic review and meta-analysis of the literature. J Urol. 2012;187(1):25-31.

12. Sadeghi R, Tabasi KT, Bazaz SM, Kakhki VR, Massoom AF, Gholami H, Zakavi SR. Sentinel node mapping in the prostate cancer. Meta-analysis. Nuklearmedizin Nucl Med. 2011;50(3):107-15.

13. Kadkhodayan S, Hasanzadeh M, Treglia G, Azad A, Yousefi Z, Zarifmahmoudi $L$, Sadeghi R. Sentinel node biopsy for lymph nodal staging of uterine cervix cancer: a systematic review and meta-analysis of the pertinent literature. Eur J Surg Oncol. 2015:41(1):1-20.

14. Shafiei S, Bagheri R, Sadri K, Jafarian AH, Attaran D, Mohammadzadeh Lari S, Basiri R, Asnaashari H, Mohammad A, Sadeghi R. Sentinel node mapping for intra-thoracic malignancies: systematic review of the best available evidence. Rev Clin Med. 2015;2(2):52-7.

15. Nyberg RH, Korkola P, Maenpaa J. Ovarian sentinel node: is it feasible? Int J Gynecol Cancer. 2011:21(3):568-72.

16. Negishi H, Takeda M, Fujimoto T, Todo Y, Ebina Y, Watari H, Yamamoto R, Minakami H, Sakuragi N. Lymphatic mapping and sentinel node identification as related to the primary sites of lymph node metastasis in early stage ovarian cancer. Gynecol Oncol. 2004;94(1):161-6.

17. Kleppe M, Brans B, Van Gorp T, Slangen BF, Kruse AJ, Pooters IN, Lotz MG, Van de Vijver KK, Kruitwagen RF. The detection of sentinel nodes in ovarian cancer: a feasibility study. J Nucl Med. 2014;55(11):1799-804.

18. Vanneuville G, Mestas D, Le Bouedec G, Veyre A, Dauplat J, Escande G, Guillot M. The lymphatic drainage of the human ovary in vivo investigated by isotopic lymphography before and after the menopause. Surg Radiol Anat. 1991:13(3):221-6

19. Momennezhad M, Zakavi SR, Dabbagh Kakhki VR, Jangjoo A, Ghavamnasiri MR, Sadeghi R. Scatterogram: a method for outlining the body during lymphoscintigraphy without using external flood source. Radiol Oncol. 2011; 45(3):184-8

20. Vanneuville G, Lebouedec G, Mestas D, Scheye T, Dauplat J, Veyre A. Functional aspects of lymphatic drainage of the human ovary in vivo explored with isotopic lymphography. Bull Assoc Anat. 1991;75(229):177-9. 
21. Kleppe M, Van Gorp T, Slangen BF, Kruse AJ, Brans B, Pooters IN, Van de Vijver KK, Kruitwagen RF. Sentinel node in ovarian cancer: study protocol for a phase 1 study. Trials. 2013;14:47.

22. Taghizadeh Kermani A, Bagheri R, Tehranian S, Shojaee P, Sadeghi R, N Krag D. Accuracy of sentinel node biopsy in the staging of non-small cell lung carcinomas: systematic review and meta-analysis of the literature. Lung Cancer. 2013;80(1):5-14.

23. Abdollahi A, Jangjoo A, Dabbagh Kakhki VR, Rasoul Zakavi S, Memar B, Naser Forghani M, Mehrabibahar M, Sadeghi R. Factors affecting sentinel lymph node detection failure in breast cancer patients using intradermal injection of the tracer. Revista Espanola de Medicina Nuclear. 2010;29(2):73-7.

24. Aliakbarian M, Memar B, Jangjoo A, Zakavi SR, Reza Dabbagh Kakhki V, Aryana K, Forghani MN, Sadeghi R. Factors influencing the time of sentinel node visualization in breast cancer patients using intradermal injection of the radiotracer. Am J Surg. 2011;202(2):199-202.

25. Sadeghi R, Forghani MN, Memar B, Rajabi Mashhadi MT, Dabbagh Kakhki VR, Abdollahi A, Zakavi SR. How long the lymphoscintigraphy imaging should be continued for sentinel lymph node mapping? Ann Nucl Med. 2009:23(6):507-10.

26. Takei H, Suemasu K, Kurosumi M, Ninomiya J, Horii Y, Inoue K, Tabei T. 99mTc-phytate is better than $99 \mathrm{mTc}$-human serum albumin as a radioactive tracer for sentinel lymph node biopsy in breast cancer. Surg Today. 2006;36(3):219-24

27. Higashi H, Natsugoe S, Uenosono Y, Ehi K, Arigami T, Nakabeppu Y, Nakajo $M$, Aikou T. Particle size of tin and phytate colloid in sentinel node identification. J Surg Res. 2004;121(1):1-4.

28. Dabbagh Kakhki VR, Jangjoo A, Tavassoli A, Asadi M, Sadri K, Fatahi Masoom A, Mehrabibahar M, Memar B, Ansari M, Sadeghi R. Sentinel node mapping for early breast cancer patients using $99 \mathrm{mTc}$-phytate: single center experience on 165 patients. Iran J Nucl Med. 2012;20(2):25-9.

29. Eftekhari M, Beiki D, Fallahi B, Arabi M, Memari F, Gholamrezanezhad A, Esmaili J, Akhzari F, Fard-Esfahani A. Assessment the diagnostic accuracy of sentinel lymph nodes lymphoscintigraphy using Technetium-99m phytate in breast cancer. Daru. 2009;17(2):83-7.

30. Shiravani Z, Hasanzadeh M, Yousefi Z, Kadkhodayan S, Sharifi N, Saeedzadeh M, Attaran M, Dabbagh Kakhki VR, Sadeghi R. The value of lateral lymphoscintigraphy images of the pelvis for gynecological cancers: Are they necessary? Iran J Nucl Med. 2014;22(2):46-50.

31. Sadeghi R, Alesheikh G, Zakavi SR, Fattahi A, Abdollahi A, Assadi M, Jangjoo A, Keshtgar M. Added value of blue dye injection in sentinel node biopsy of breast cancer patients: do all patients need blue dye? Int J Surg. 2014;12(4):325-8.

32. Frontado LM, Brouwer OR, van den Berg NS, Matheron HM, Vidal-Sicart S, van Leeuwen FW, Valdes Olmos RA. Added value of the hybrid tracer indocyanine green-99mTc-nanocolloid for sentinel node biopsy in a series of patients with different lymphatic drainage patterns. Revista Espanola de Medicina Nuclear e Imagen Molecular. 2013;32(4):227-33.

33. Takei H, Suemasu K, Kurosumi M, Horii Y, Ninomiya J, Kamimura M, Naganuma R, Uchida K, Igarashi K, Inoue K, et al. Added value of the presence of blue nodes or hot nodes in sentinel lymph node biopsy of breast cancer. Breast Cancer. 2006:13(2):179-85.

34. Ramin S, Azar FP, Malihe H. Methylene blue as the safest blue dye for sentinel node mapping: emphasis on anaphylaxis reaction. Acta Oncol. 2011;50(5):729-31.

35. Jangjoo A, Forghani MN, Mehrabibahar M, Sadeghi R. Anaphylaxis reaction of a breast cancer patient to methylene blue during breast surgery with sentinel node mapping. Acta Oncol. 2010;49(6):877-8.

36. Jangjoo A, Forghani MN, Mehrabibahar M, Rezapanah A, Kakhki VR, Zakavi SR, Ghavamnasiri MR, Kashani I, Hashemian F, Sadeghi R. Comparison of early and delayed lymphoscintigraphy images of early breast cancer patients undergoing sentinel node mapping. Nucl Med Commun. 2010;31(6):521-5.

37. Sadeghi R, Forghani MN, Memar B, Abdollahi A, Zakavi SR, Mashhadi MT, Raziee HR, Tavassoli A, Kakhki VR. Comparison of pre-operative lymphoscintigraphy with inter-operative gamma probe and dye technique regarding the number of detected sentinel lymph nodes. Hell J Nucl Med. 2009;12(1):30-2.

38. Klapdor R, Langer F, Gratz KF, Hillemanns P, Hertel H. SPECT/CT for SLN dissection in vulvar cancer: Improved SLN detection and dissection by preoperative threedimensional anatomical localisation. Gynecol Oncol. 2015;138(3):590-6.

39. Mucke J, Klapdor R, Schneider M, Langer F, Gratz KF, Hillemanns P, Hertel H. Isthmocervical labelling and SPECT/CT for optimized sentinel detection in endometrial cancer: technique, experience and results. Gynecol Oncol. 2014:134(2):287-92.

40. Sadeghi R. Sentinel node mapping diagnostic studies warrant a unique reporting criteria: Comment on Xiong et al. systematic review. Eur J Surg Oncol. 2014:40(8):1025-6

41. Giammarile F, Bozkurt MF, Cibula D, Pahisa J, Oyen WJ, Paredes P, Olmos RV, Sicart SV. The EANM clinical and technical guidelines for lymphoscintigraphy and sentinel node localization in gynaecological cancers. Eur J Nucl Med Mol Imaging. 2014;41(7):1463-77.

42. Kadkhodayan S, Farahabadi EH, Yousefi Z, Hasanzadeh M, Sadeghi R. Inappropriate intra-cervical injection of radiotracer for sentinel lymph node mapping in a uterine cervix cancer patient: importance of lymphoscintigraphy and blue dye injection. Asia Oceania J Nucl Med Biol. 2014;2(2):135-7.

43. Nugent N, Hill AD, Casey M, Kelly L, Dijkstra B, Collins CD, McDermott EW, O'Higgins N. Safety guidelines for radiolocalised sentinel node resection. Ir J Med Sci. 2001;170(4):236-8.

\section{Submit your next manuscript to BioMed Central and we will help you at every step:}

- We accept pre-submission inquiries

- Our selector tool helps you to find the most relevant journal

- We provide round the clock customer support

- Convenient online submission

- Thorough peer review

- Inclusion in PubMed and all major indexing services

- Maximum visibility for your research

Submit your manuscript at www.biomedcentral.com/submit
) Biomed Central 